\title{
Tata Kelola Perusahaan dan Audit Report Lag pada Perusahaan Financial yang Terdaftar di BEI
}

\author{
Serly $^{1 *}$ \\ Universitas Internasional Batam \\ serly@uib.ac.id
}

*Penulis korespondensi

Diajukan : 15 Juli 2021

Disetujui : 25 Agustus 2021

Dipublikasi : 26 Agustus 2021

\begin{abstract}
This research seeks to examine the factors that affect the audit report lag of financial companies from 2014 through 2018. Several factors are selected under this study consist of audit quality, audit committee, auditor changes, board of directors, frequency of board meetings, the ability of the board of directors, gender of the board of directors, risk management committee, company size, and loss. 86 financial companies are sampled in this study. The researcher gained the data using the purposive sampling method. The findings indicate the financial company listed on the Indonesian Stock Exchange needs an average of 71 days to submit an audit financial report after the closing date. The variable of frequency of board meetings has a significant positive response for the audit report lag, while the impact of the board of directors and risk management committee is negative. Meanwhile, variables of the audit quality, audit committee, auditor changes, director expertise, board gender diversity, company size, and loss did not show significant influence on audit report lag. Overall, the finding in this study provides that monitoring activities through board meetings will allow management to discuss how to improve company performance and also reduced the delay of corporate disclosure information to stakeholders.
\end{abstract}

Keywords: audit report lag; corporate governance

\section{PENDAHULUAN}

Laporan keuangan digunakan sebagai salah sarana penyampaian informasi dari pihak manajemen kepada penggunaan informasi, dimana informasi yang tercantum didalamnya menampilkan kinerja perusahaan dan kondisi keuangan pada suatu periode yang telah ditetapkan (Sujarweni, 2016). Penyajian laporan keuangan harus disajikan sesuai dengan ketentuan dan standar yang berlaku. Hal ini diterapkan untuk mempermudah pengguna laporan (internal dan eksternal) dalam menginterpretasi informasi dari laporan keuangan (Weygandt et al., 2013).

Berdasarkan ketentuan Badan Pengawasan Pasar Modal dan Lembaga Keuangan Nomor X.K.6, Lampiran Keputusan Ketua BAPEPAM-LK Nomor: KEP-431/BL/2012 tentang pelaporan laporan tahunan perusahaan atau perusahaan publik, perusahaan go public diwajibkan menyajikan laporan keuangan tahunan audited paling lambat empat bulan setelah tutup buku tahunan. Keterlambatan audit yang melewati batas yang telah ditentukan akan menyebabkan keterlambatan dalam penyampaian laporan keuangan dan mempengaruhi kualitas laporan keuangan tersebut. Keterlambatan penyampaian laporan keuangan diatur Peraturan Pemerintah Nomor 45 Tahun 1995, pasal 63 huruf e mengenai Penyelenggaraan Kegiatan di Bidang Pasar Modal. Setiap perusahaan yang terdaftar secara efektif dikenakan denda untuk keterlambatan penyampaian laporan keuangan kepada BAPEPAM. Nominal denda dimulai dari sebesar satu juta rupiah per hari atas keterlambatan penyampaian laporan setiap hari dan jumlah denda paling banyak hingga lima ratus juta.

Tata kelola perusahaan menjelaskan hubungan pihak-pihak berkepentingan dalam perusahaan dalam penentuan kinerja perusahaan (Violita \& Sulasmiyati, 2017). Tata kelola perusahaan berawal dari teori keagenan yang mencakup hubungan dewan komisaris, manajemen perusahaan, para 
pemegang saham, dan stakeholders (Jensen \& Meckling, 1976). Penerapan tata kelola yang baik dalam perusahaan diharapkan dapat memaksimalkan kinerja dan meminimalkan keterlambatan dalam penyampaian laporan keuangan. Dimana dalam tata kelola itu sendiri, terdapat peran dewan direksi dan komite audit yang memainkan peran dalam pemantauan internal perusahaan. Tata kelola melalui karakteristik dewan yakni ukuran dewan direksi, frekuensi pertemuan dewan direksi, keahlian dewan direksi, jenis kelamin dewan direksi dan karakteristik komite audit berupa kualitas audit, ukuran komite audit, pergantian auditor dalam meminimalisasi audit report lag. Dalam hal ini, mekanisme tata kelola perusahaan memainkan peranan penting dalam ketepatan waktu pelaporan keuangan perusahaan. Ketepatan waktu pelaporan keuangan dihitung mulai dari tanggal tutup buku tahunan hingga tanggal laporan dipublikasikan kepada publik (Firnanti \& Karmudiandri, 2020). Menurut Al-Juaidi dan Al-Afifi (2016), tingkat profitabilitas mempengaruhi audit report lag suatu perusahaan. Hal ini dikarenakan ketika profitabilitas mengalami penurunan atau bahkan minus, perusahaan akan cenderung menunda pelaporan hasil laporan keuangan tersebut untuk menghindari kekecewaan investor.

Tujuan penelitian yakni menguji pengaruh kualitas audit, ukuran komite audit, pergantian auditor, ukuran dewan direksi, frekuensi pertemuan dewan direksi, keahlian dewan direksi, jenis kelamin dewan direksi, ukuran komite manajemen risiko, ukuran perusahaan, dan kerugian terhadap audit report lag. Perusahaan finansial dipilih sebagai objek penelitian.

Hasil penelitian ini diharapkan berkontribusi, yakni (1) bagi perusahaan finansial, dapat menjadi pedoman bagi perusahaan agar lebih mempertimbangkan dan memahami aspek-aspek yang menjadi penyebab keterlambatan pelaporan audit sehingga menghindari perusahaan dari keterlambatan pelaporan dan sanksi sesuai dengan peraturan yang berlaku. (2) bagi investor, penelitian ini diharapkan menjadi informasi tambahan dalam pengambilan keputusan investasi di sektor finansial. (3) bagi para akademisi untuk menambah wawasan tentang audit report lag dan faktor-faktor yang mempengaruhinya. Hasil ini juga, bisa menjadikan pedoman untuk dipertimbangkan dan arahan untuk dikembangkan bagi penelitian selanjutnya.

\section{Audit Report Lag}

\section{STUDI LITERATUR}

Menurut Ashton et al. (1989), audit report lag adalah keadaan dimana perusahaan terlambat dalam penyampaian laporan keuangan. Keterlambatan ini dapat disebabkan oleh internal maupun eksternal perusahaan. Menurut Al-Juaidi dan Al-Afifi (2016), keterlambatan penyampaian laporan keuangan dari sisi internal atau manajemen perusahaan yakni nilai profitabilitas yang rendah atau nilai yang minus bahkan rugi. Kondisi ini dinilai oleh perusahaan akan menyebabkan signal negatif bagi para investor. Sehingga perusahaan melakukan penundaan penyampaian laporan keuangan. Sedangkan penyebab keterlambatan dari sisi eksternal perusahaan, salah satu dapat disebabkan oleh keterbatasan auditor dalam melakukan pemeriksaan baik dikarenakan jumlah transaksi yang banyak maupun tingkat kesulitan/kerumitan suatu transaksi yang akan diselesaikan.

Audit report lag dikelompokkan menjadi tiga menurut Putri dan Januarti (2014), yakni preliminary lag, auditor's signature lag, dan total lag.

a. Preliminary lag: waktu antara tanggal tutup buku tahunan fiskal hingga tanggal laporan keuangan diterima oleh pihak pasar modal.

b. Auditor's signature lag: waktu antara tanggal tutup buku tahunan fiskal hingga tanggal yang tercatat dalam laporan auditor.

c. Total lag: waktu antara tanggal tutup buku tahunan fiskal hingga tanggal diterimanya laporan keuangan tahunan yang sudah dipublikasi oleh pasar modal.

Herawaty dan Rusmawan (2019) menyimpulkan bahwa semakin pendek audit report lag maka memberikan memanfaat yang besar bagi pengguna informasi laporan keuangan. Hal ini dikarenakan waktu pengungkapan informasi dari laporan keuangan mempengaruhi nilai dari laporan tersebut (Rezaei \& Saleh, 2016).

\section{Kualitas Audit terhadap Audit Report Lag}

Pemeriksaan dan penyampaian laporan keuangan yang telah di audit kepada komite audit diharapkan dilakukan oleh auditor professional. Hal ini dikarenakan dengan adanya auditor 
profesional maka perusahaan telah memenuhi standar audit dan regulasi dari tata kelola perusahaan (Al-Juaidi \& Al-Afifi, 2016). Pemilihan kantor audit Big 4 menjadi salah satu faktor pendukung agar perusahaan terhindar dari keterlambatan penyampaian laporan keuangan (Pradipta \& Zalukhu, 2020). Kantor audit Big 4 dinilai memiliki sumber daya yang memumpuni baik dari sisi auditor dengan kualitas yang baik dan terlatih hingga teknologi audit yang lebih canggih. Selain itu, kantor akuntan publik Big 4 memiliki insentif yang kuat dalam penyelesaian tugas dengan tujaun untuk menjaga reputasi, dipercaya dalam mendeteksi kesalahan, dan kecurangan dalam pelaporan keuangan. Perusahaan menilai bahwa semakin lama jangka waktu yang digunakan untuk mempersiapkan laporan keuangan maka kualitas audit akan semakin baik. Hal ini dikarenakan kualitas auditor dapat diukur dari temuan atas kesalahan penyajian laporan keuangan yang bernilai material ataupun tidak material dan kemudian disampaikan melalui opini audit. Dari penjelasan tersebut, maka hipotesis yang diusulkan yakni:

\section{$\mathbf{H}^{1}$ : Kualitas audit berpengaruh signifikan terhadap audit report lag.}

\section{Ukuran Komite Audit terhadap Audit Repot Lag}

Badan Pengawasan Pasar Modal No. IX.I.5 menerangkan komite audit sebagai sebuah komite yang mewakili para komisaris dalam menyelesaikan tugas dari dewan komisaris. Jumlah anggota komite audit yang ideal yakni paling kurang berjumlah 3 orang dengan komposisi 1 ketua komite dan anggota lainnya. Anggota komite audit diharapkan merupakan pihak luar/tidak terkait dengan perusahaan dan memiliki keahlian dibidang akuntansi (Arif \& Nauman Anees, 2012). Menurut AlJuaidi dan Al-Afifi (2016), komite audit merupakan perantara tangan dewan komisaris dalam melaksanakan asas-asas tata kelola yang baik dan terbuka. Komite audit juga dinilai mampu dalam peningkatan kualitas audit dan menarik kepercayaan publik atas laporan keuangan yang disajikan dikarenakan penyusunan laporan keuangan berada dalam pengawasan komite audit. Adanya komite audit akan memperkuat komunikasi antara manajemen perusahaan dengan auditor eksternal. Semakin meningkatnya jumlah komite audit maka kualitas pengawasan dan penyelesaian masalah perusahaan menjadi lebih cepat. Pendapat berbeda disampaikan oleh Bhuiyan dan D'Costa (2020), dimana terjadi peningkatan audit report lag ketika perusahaan memiliki jumlah komite audit yang tinggi. Sehingga hipotesis yang diusulkan yakni:

\section{$\mathbf{H}^{2}$ : Ukuran komite audit berpengaruh signifikan terhadap audit report lag.}

\section{Pergantian Auditor terhadap Audit Report Lag}

Pergantian auditor merupakan kondisi dimana perusahaan melakukan perubahan atau pergantian penggunaan jasa auditor lama ke jasa auditor baru. Pergantian auditor dapat disebabkan karena ketidakpuasan klien terhadap jasa auditor yang diberikan. Pergantian auditor dinilai dapat menimbulkan audit report lag. Kondisi auditor baru yang masih beradaptasi dan membutuhkan waktu dalam memahami lini bisnis perusahaan (Arif \& Nauman Anees, 2012). Auditor akan membuat perencanaan audit dan bekerja secara profesional sebelum melaksanakan proses audit. Untuk menghindari lamanya proses audit yang dilakukan, pada umumnya auditor akan melakukan penerimaan klien baru jauh sebelum tahun fiskal berakhir (Sylviana, 2019). Keputusan BAPEPAM dan LK No. KEP-310/BL/2008 dan KEP-86/BL/2011 mengatur pemberian jasa audit umum atas laporan keuangan klien. Kantor Akuntan Publik hanya dapat memberikan jasa audit kepada 1 klien yang sama paling lama untuk enam tahun buku berturut-turut dan oleh seorang akuntan paling lama untuk tiga tahun buku berturut-turut. Hipotesis yang terbentuk yakni:

\section{$\mathbf{H}^{3}$ : Pergantian auditor berpengaruh signifikan terhadap audit report lag.}

\section{Ukuran Dewan Direksi terhadap Audit Report Lag}

Joened dan Damayanthi (2016) mengungkapkan perusahaan dinilai telah menerapkan tata kelola dengan baik jika memiliki komponen yakni ukuran dewan direksi. Dewan direksi memainkan peranan penting dalam menghindari keterlambatan dalam penyampaian laporan keuangan. Komite risiko dan komite audit memiliki pengaruh lebih besar di dalam perusahaan dibandingkan dengan dewan direksi (Klein, 1998). Pendapat Klein (1998) ini dibantah oleh Jiraporn et al. (2008) dimana dewan direksi wajib dibentuk dan berkewajiban dalam memainkan peranan penting dalam pengambilan keputusan guna meningkatkan kinerja perusahaan. 
Dewan direksi yang besar dinilai mempunyai kemampuan dalam pengambilan keputusan dan dapat menjalankan tugas lebih baik serta dinilai dapat meningkatkan ketepatan waktu pelaporan keuangan. Pengaruh positif antara ukuran dewan direksi dan audit report lag juga dikemukakan oleh Jao dan Crismayani (2018) dimana semakin besar ukuran dewan maka pengawasan yang dilakukan oleh dewan direksi jauh lebih baik. Sehingga memberikan efek positif bagi peningkatan kinerja perusahaan dan peningkatan kualitas keuangan perusahaan serta mengurangi audit report lag. Disisi lain, banyaknya anggota dewan direksi dapat menyebabkan kurangnya partisipasi antar anggota, timbulnya masalah dalam komunikasi yang berimbas pada penurunan kemampuan, dan mengalami kesulitan dalam mencapai suatu kesepakatan (Dimitropoulos \& Asteriou, 2010). Sebaliknya, ukuran dewan direksi yang anggotanya minim dinilai lebih mudah dalam tatanan birokrasi dan mampu memberikan pengawasan pada proses pelaporan keuangan.

\section{$\mathbf{H}^{4}$ : Ukuran dewan direksi berpengaruh signifikan terhadap audit report lag.}

\section{Frekuensi Pertemuan Dewan Direksi terhadap Audit Report Lag}

Peraturan Badan Pengawasan Pasar Modal No. IX.I.5 mengenai pembentukan dan pedoman bagi direksi dalam melaksanakan tugas dan kewajibannya. Menurut Jensen dan Meckling (1976), kegiatan dewan mencerminkan komitmen direksi dalam mengindentifikasi, menangani, dan mengelola risiko dan sebagai bentuk mekanisme pengendalian internal yang baik pada operasional perusahaan. FCGI (2002) menyatakan komite dewan direksi harus melakukan pertemuan sebanyak tiga hingga empat kali dalam setahun atau satu periode yang telah ditentukan guna untuk menjalankan tanggung jawab dan tugas yang telah dibebankan. Pembaharuan setiap peraturan perusahaan, kemampuan penyelesaian setiap permasalahan, dan pemahaman atas setiap perubahan di perusahaan juga menjadi alasan dilakukannya rapat (Suryono \& Prastiwi, 2011).

Perusahaan dengan tingkat rapat pertemuan dewan direksi yang tinggi membentuk manajemen yang mampu meningkatkan kinerja yang terarah dan menerbitkan laporan tahunan secara tepat waktu. Hal ini menjelaskan bahwa mekanisme tata kelola perusahaan telah dikelola secara efektif. Frekuensi pertemuan dewan direksi juga berfungsi sebagai salah satu cara bagi dewan direksi dalam melakukan pengawasan internal dengan tujuan produktivitas dan profesionalisme perusahaan meningkat (Kuslihaniati \& Hermanto, 2016).

\section{$\mathbf{H}^{5}$ : Frekuensi pertemuan dewan direksi berpengaruh signifikan terhadap audit report lag.}

\section{Keahlian Dewan Direksi terhadap Audit Report Lag}

Keahlian dewan direksi diperlukan oleh perusahaan finansial dan non finansial karena dinilai lebih tepat dan pasti dalam pengambilan keputusan bagi perusahaan. Latar belakang dewan direksi mampu mempengaruhi pemgambilan keputusan (Ika \& Mohd Ghazali, 2012). Anggota dewan direksi dengan keahlian keuangan akuntansi dinilai lebih profesional dan sigap dalam mengambil keputusan sehingga memberikan pengaruh secara negatif pada audit report lag. Perusahaan memiliki dewan direksi yang memahami secara dalam keuangan, memberikan potensi untuk memperpendek audit report lag.

\section{$\mathbf{H}^{6}$ : Keahlian dewan direksi berpengaruh signifikan terhadap audit report lag.}

\section{Jenis Kelamin Dewan Direksi terhadap Audit Report Lag}

Teori agensi menjelaskan bahwa jenis kelamin berpengaruh terhadap keefektifan dewan direksi di dalam perusahaan. Direksi dengan jenis kelamin perempuan dinilai lebih konservatif secara finansial, terikat secara etis, serta memilih tidak mengambil risiko dibandingkan dengan direksi laki-laki. Perempuan cenderung lebih rapi dan teliti dalam menyusun dan menyiapkan tugas maupun laporan dibandingkan laki-laki. Hal ini sangat membantu akuntan publik dalam menyelesaikan laporan audit sehingga kondisi ini memungkinkan keterlambatan laporan audit sangat rendah (Al-Juaidi \& Al-Afifi, 2016). Harjoto et al. (2015) dan Frischanita (2018) menyatakan CEO perempuan lebih banyak mempublikasi laporan keuangan secara tepat waktu. Ini dikarenakan CEO perempuan dinilai lebih peka terhadap tekanan pada pasar modal dan berusaha untuk melakukan penekanan waktu audit report lag.

$\mathrm{H}^{7}$ : Jenis kelamin dewan direksi berpengaruh signifikan terhadap audit report lag. 


\section{Ukuran Komite Manajemen Risiko terhadap Audit Report Lag}

Komite manajemen risiko merupakan sebuah komite yang dibentuk dan bertanggungjawab secara langsung kepada direksi. Tujuan dibentuknya komite manajemen risiko adalah untuk memantau kinerja manajemen risiko global korporasi (Bank of New York Mellon, 2018). Al-Juaidi dan Al-Afifi (2016) menyatakan bahwa dibutuhkan sumber daya yang cukup dan terpercaya dalam menjalankan fungsi dari komite manajemen risiko. Keberagaman pendapat, keahlian masingmasing anggota, keefektifan dalam menyelesaikan masalah menjadi kunci utama dari komite manajemen risiko. Kebijakan dan strategi dalam mengelola risiko yang ada di dalam perusahaan memiliki pengaruh positif bagi calon investor dan pengguna lain dalam menilai perusahaan tersebut. Selain itu, hal ini juga menggambarkan bagaimana perusahaan kinerja keuangan sehingga meningkatkan kepercayaan investor terhadap perusahaan.

\section{$\mathbf{H}^{8}$ : Ukuran komite manajemen risiko berpengaruh signifikan terhadap audit report lag.}

\section{Ukuran Perusahaan terhadap Audit Report Lag}

Al-Juaidi dan Al-Afifi (2016) menuturkan bahwa ukuran perusahaan menunjukkan skala dari aset yang dimiliki. Sebagian besar penelitian terdahulu menggunakan total aset dalam mengukur skala ukuran perusahaan. Ukuran perusahaan dihitung menggunakan log natural dari total aset perusahaan yang dimaksud untuk mengurangi data yang berlebihan sehingga memberikan pengaruh negatif dengan audit report lag. Al-Juaidi dan Al-Afifi (2016) dan Ustman (2020) sependapat bahwa laporan audit akan selesai lebih lama ketika total aset berskala besar dan sebaliknya. Pendapat berbeda disampaikan oleh Juanita dan Satwiko (2012), Jaggi dan Tsui (1999) yang menyatakan bahwa perusahaan besar dinilai dapat menyelesaikan laporan keuangan audit dalam jangka waktu lebih pendek dibandingkan perusahaan skala kecil. Hal ini dikarenakan perusahaan besar dengan kompleksitas besar diimbangi dengan pengendalian internal yang lebih baik sehingga dapat mengurangi kesalahan dalam laporan keuangan (Fujianti \& Satria, 2020).

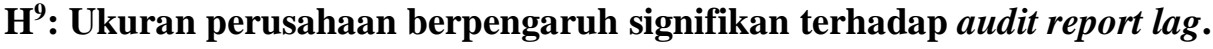

\section{Kerugian terhadap Audit Report Lag}

Al-Juaidi dan Al-Afifi (2016) mengatakan faktor risiko dalam suatu perusahaan dapat diukur baik dengan keuntungan maupun kerugian. Audit report lag dapat disebabkan karena perusahaan mengalami kerugian dan berusaha menunda kabar buruk sehingga perusahaan dapat meminta auditor untuk menyusun ulang laporan auditnya. Kerugian yang dialami perusahaan dianggap sebagai kabar buruk baru bagi investor sehingga manajemen berusaha untuk memperlambat laporan keuangannya serta auditor cenderung lebih berhati-hati dalam melakukan pemeriksaan audit (Herawaty \& Rusmawan, 2019). Audit report lag juga dapat disebabkan oleh auditor yang lebih memperhatikan setiap akun dalam sistem audit dilakukan karena bisa saja kerugian ini terjadi diakibatkan dari kecurangan yang dilakukan perusahaan. Laba rugi merupakan hasil kinerja suatu perusahaan. Perusahaan yang memiliki laba yang tinggi bisa membagikan hasil kepada pemegang saham. Informasi laba rugi perusahaan bisa dijadikan sebagai dasar dalam mengambil keputusan bagi investor untuk membeli ataupun menjual saham perusahaan yang dimiliki.

\section{$\mathbf{H}^{10}$ : Kerugian berpengaruh signifikan terhadap audit report lag.}

\section{Rancangan Penelitian}

\section{METODE}

Penelitian disimpulkan sebagai kegiatan ilmiah menggunakan latar belakang, metodologi, teori, dan data untuk diolah sehingga mengetahui permasalahan yang sebenarnya (Sujarweni, 2016). Penelitian ini dinilai sebagai penelitian arsip karena pada penelitian ini menggunakan kumpulan data yang diperoleh dari data eksternal yaitu seperti data akta dan data yang dipublikasikan. Penelitian kausal komparatif ini mengkaji hubungan sebab akibat antara dua variabel atau lebih dalam satu fenomena. Menurut Indriantoro dan Supomo (2016), minimal data yang dipakai dalam penelitian historikal dengan rentang waktu ke waktu yakni lima tahun.

\section{Objek Penelitian}

Sampel penelitian diperoleh sesuai dengan kriteria yang dibutuh pada penelitian dengan metode 
purposive sampling (Indriantoro \& Supomo, 2016). Kriteria penelitian yakni (1) perusahaan finansial dengan laporan keuangan tahunan lengkap pada rentang waktu 2014- 2018. (2) laporan keuangan tahunan telah diaudit oleh auditor eksternal. (3) data yang diperlukan tersedia pada laporan keuangan tahunan.

\section{Pengukuran Variabel}

Variabel yang digunakan pada penelitian adalah variabel dependen dan variabel independen. Metode pengukuran setiap variabel pada penelitian ini sebagai berikut:

Tabel 1 Pengukuran Variabel

\begin{tabular}{|l|l|}
\hline \multicolumn{1}{|c|}{ Variabel } & \multicolumn{1}{c|}{ Pengukuran } \\
\hline Audit report lag & $\begin{array}{l}\text { Masa yang diperlukan untuk memperoleh laporan keuangan auditor } \\
\text { secara independen mulai dari tanggal tutup buku perusahaan yaitu per } \\
\text { 31 Desember hingga tanggal yang tercantum pada laporan audit yang } \\
\text { diterbitkan. }\end{array}$ \\
\hline Kualitas audit & $1=$ jika diaudit oleh Big 4; $0=$ jika diaudit selain dari Big 4. \\
\hline Ukuran komite audit & Jumlah anggota komite audit \\
\hline Pergantian auditor & $\begin{array}{l}1=\text { jika mengganti auditor yang baru dari tahun sebelumnya. } \\
0=\text { jika tidak mengganti auditor yang baru dari tahun sebelumnya. }\end{array}$ \\
\hline Ukuran dewan direksi & Jumlah anggota dewan direksi \\
\hline $\begin{array}{l}\text { Frekuensi pertemuan } \\
\text { dewan direksi }\end{array}$ & Jumlah pertemuan dewan direksi dalam satu tahun \\
\hline Keahlian dewan direksi & $\begin{array}{l}\text { Rasio anggota dewan direksi ahli dibidang keuangan dari total dewan } \\
\text { direksi }\end{array}$ \\
\hline $\begin{array}{l}\text { Jenis kelamin dewan } \\
\text { direksi }\end{array}$ & $\begin{array}{l}1=\text { jika salah satu dewan direksinya perempuan. } \\
0=\text { jika salah satu dewan direksinya laki-laki. }\end{array}$ \\
\hline $\begin{array}{l}\text { Ukuran komite } \\
\text { manajemen risiko }\end{array}$ & Jumlah anggota komite manajemen risiko \\
\hline Ukuran perusahaan & Log total aset \\
\hline Kerugian & Kerugian =1, laporan keuangan bersih rugi; Kerugian =0, sebaliknya. \\
\hline & Sumber: Ahmed dan Che-Ahmad (2016) \\
\hline
\end{tabular}

\section{Metode Analisis Data}

Penelitian ini menggunakan analisis regresi panel. Data yang dipakai merupakan gabungan data cross sectional dan data time series.

\section{Statistik Deskriptif}

\section{HASIL}

Laporan keuangan tahunan perusahaan finansial yang terpublikasi setiap tahun dengan rentan tahun yakni 2014 sampai dengan 2018. Data yang digunakan merupakan data sekunder yang diperoleh dari laporan keuangan tahunan tersebut. Terdapat 96 perusahaan finansial yang tercatat pada Bursa Efek Indonesia (BEI). Sejumlah 86 perusahaan finansial sebagai sampel penelitian. Hal ini dikarenakan 18 perusahaan finansial lainnya tidak menerbitkan laporan keuangan tahunan setiap tahun, perusahaan finansial yang baru melakukan penawaran umum perdana, dan laporan keuangan tahunan yang kurang lengkap dan tidak memenuhi kriteria dalam penelitian ini. Sehingga total data pada penelitian sebanyak 378 data.

Tabel 2 Hasil Uji Statistik Deskriptif

\begin{tabular}{|l|l|l|l|l|l|}
\hline Variabel & N & Minimal & Maksimal & $\begin{array}{l}\text { Rata- } \\
\text { rata }\end{array}$ & $\begin{array}{l}\text { Std. } \\
\text { Deviasi }\end{array}$ \\
\hline Audit Report Lag & 378 & 22 & 105 & 70,83 & 17,19 \\
\hline Ukuran Dewan Direksi & 378 & 2 & 14 & 4,94 & 2,50 \\
\hline Ukuran Komite Audit & 378 & 2 & 7 & 3,48 & 0,89 \\
\hline
\end{tabular}


Owner: Riset \& Jurnal Akuntansi

e-ISSN : 2548-9224 |p-ISSN : 2548-7507

Volume 5 Nomor 2, Agusus 2021

DOI : https://doi.org/10.33395/owner.v5i2.498

\begin{tabular}{|l|l|l|l|r|c|}
\hline Ukuran Komite Manajemen Risiko & 378 & 1 & 8 & 3,56 & 1,01 \\
\hline $\begin{array}{l}\text { Frekuensi Pertemuan Dewan } \\
\text { Direksi }\end{array}$ & 378 & & & & 100 \\
\hline Keahlian Dewan Direksi & 378 & 0 & 1 & 0,39 & 12,29 \\
\hline Ukuran Perusahaan (dalam miliar) & 378 & 10,70 & 15,07 & 12,80 & 0,21 \\
\hline Valid N (listwise) & 378 & & & & \\
\hline
\end{tabular}

Sumber: Data sekunder diolah (2021)

Berdasarkan hasil uji, diketahui bahwa dibutuhkan waktu paling cepat 22 hari dan paling lama 105 hari bagi perusahaan finansial dalam menyampaikan laporan keuangan audit dari tanggal tutup buku tahunan. Rata-rata diperlukan waktu 70 hari dari tanggal tutup buku tahunan bagi perusahaan finansial menyampaikan ataupun mengirimkan laporan keuangan tahunan. Hasil dari rata-rata variabel audit report lag sesuai dengan ketentuan yang berlaku dalam peraturan OJK No. 29/POJK/04/2016 tentang laporan tahunan emiten atau perusahaan publik yang menyatakan bahwa perusahaan wajib menyampaikan laporan tahunan paling lambat adalah akhir bulan keempat setelah tahun buku berakhir.

Perusahaan finansial pada penelitian ini memiliki paling sedikit 2 anggota direksi dan paling banyak 14 orang direksi serta rata-rata keseluruhan ukuran direksi 5 orang. Sehingga dapat disimpulkan bahwa perusahaan finansial pada penelitian ini telah memenuhi syarat wajib yakni paling kurang dua orang direksi sesuai dengan dalam peraturan OJK No. 29/POJK/04/2016 tentang direksi dan dewan komisaris emiten atau perusahaan publik.

Variabel ukuran komite audit menunjukkan angka dua, yang menyatakan perusahaan finansial pada penelitian ini memiliki minimal 2 orang komite audit dan maksimal komite audit adalah 7 orang komite audit yang terdiri atas satu ketua dan anggota komite audit. Perusahaan finansial ratarata terdiri atas 3 orang komite audit dan dianggap memenuhi OJK No. 55/POJK/04/2015 perihal jumlah komite audit dalam setiap perusahaan finansial harus ada 3 orang.

Ukuran komite manajemen risiko menampilkan nilai 1, yang artinya setiap perusahaan memiliki minimal 1 anggota komite manajemen risiko. Jumlah anggota terbanyak yakni 8 orang anggota yang terdiri dari ketua dan anggota manajemen risiko. Hal ini dapat peneliti simpulkan bahwa seluruh perusahaan finansial mematuhi POJK No. 1/POJK.05/2015 terkait penerapan manajemen risiko bagi lembaga jasa keuangan non-bank dan POJK No. 18/POJK.03/2016 terkait penerapan manajemen risiko bagi bank umum.

Perusahaan finansial pada penelitian ini telah memenuhi ketentuan POJK No. 33/POJK.04/2014. Dimana rata-rata frekuensi pertemuan dewan direksi dilakukan sebanyak 17 kali sampai 18 kali dalam jangka waktu satu tahun. Hasil uji juga menunjukkan bahwa terdapat perusahaan finansial yang sama sekali tidak memiliki dewan direksi dengan pengalaman di bagian keuangan ataupun pendidikan dalam bidang akuntansi.

Variabel ukuran perusahaan menunjukkan nilai terendah total aset sebesar Rp10.709.673.110.000 yang dimiliki oleh Danasupra Erapacific tahun 2014. Nilai maksimal total aset dari Bank Mandiri tahun 2018 yakni sebesar Rp15.079.995.540.000. Selain itu, diperoleh nilai rata-rata aset sebesar Rp12.820.047.390.000 yang membuktikan rata-rata perusahaan finansial memiliki total aset perusahaan yang tinggi. Badan Pengawasan Pasar dan Modal No.11/PM/1997 tertuang bahwa total aset perusahaan melebihi 100 miliar rupiah, maka perusahaan tersebut masuk dalam kategori perusahaan berukuran besar.

Tabel 3 Hasil Uji Statistik Deskriptif (Variabel Dummy)

\begin{tabular}{|l|c|c|c|}
\hline Variabel & Kategori & Frekuensi & Persentase \\
\hline Kualitas Audit & $0=$ Non-Big 4 & 215 & 56,90 \\
\hline \multirow{3}{*}{ Pergantian Auditor } & $1=$ Big 4 & 163 & 43,10 \\
\cline { 2 - 4 } & $\begin{array}{c}1=\text { jika mengganti auditor yang baru } \\
\text { dari tahun sebelumnya. }\end{array}$ & 320 & 84,70 \\
\cline { 2 - 4 } & $\begin{array}{c}0=\text { jika tidak mengganti auditor yang } \\
\text { baru dari tahun sebelumnya }\end{array}$ & 58 & 15,30 \\
\hline
\end{tabular}


Owner: Riset \& Jurnal Akuntansi

e-ISSN : 2548-9224 |p-ISSN : 2548-7507

Volume 5 Nomor 2, Agusus 2021

\begin{tabular}{|l|l|l|l|}
\hline $\begin{array}{l}\text { Jenis Kelamin Dewan } \\
\text { Direksi }\end{array}$ & $0=$ Jika tidak ada perempuan & 173 & 45,80 \\
\hline & 1 = Jika ada perempuan & 205 & 54,20 \\
\hline Kerugian & 0 = Untung & 322 & 85,20 \\
\hline & 1 = Rugi & 56 & 14,80 \\
\hline
\end{tabular}

Sumber: Data sekunder diolah (2021)

Terdapat 215 perusahaan finansial dengan persentase sebesar 56,90\% yang menggunakan jasa KAP Non-Big 4 dan menunjukkan bahwa penggunaan jasa auditor dalam pemeriksaan laporan keuangan perusahaan finansial masih didominasi oleh jasa auditor KAP Non-Big 4. Pergantian auditor baru dilakukan oleh 320 perusahaan finansial selama periode penelitian. Terdapat 45,80\% perusahaan finansial tidak memiliki direksi perempuan dalam susunan dewan direksi dan sebesar $54,20 \%$ perusahaan finansial dilengkapi dengan anggota perempuan dalam struktur dewan direksi. Variabel kerugian menunjukkan bahwa $85,20 \%$ perusahaan finansial memiliki kinerja yang baik dan dapat mempertahankan perusahaan dalam kondisi profit.

Tabel 4 Hasil Uji t

\begin{tabular}{|l|c|l|l|l|}
\hline Variabel & Koefisien & Prob & Kesimpulan & Hipotesis \\
\hline Kualitas audit & 1,000 & 0,726 & Tidak signifikan & Tidak terbukti \\
\hline Ukuran komite audit & 0,899 & 0,410 & Tidak signifikan & Tidak terbukti \\
\hline Pergantian auditor & 2,86 & 0,068 & Tidak signifikan & Tidak terbukti \\
\hline Ukuran dewan direksi & $-2,538$ & 0,002 & Signifikan & Terbukti \\
\hline $\begin{array}{l}\text { Frekuensi pertemuan } \\
\text { dewan direksi }\end{array}$ & 0,159 & 0,052 & Signifikan & Terbukti \\
\hline Keahlian dewan direksi & $-3,88$ & 0,698 & Tidak signifikan & Tidak terbukti \\
\hline $\begin{array}{l}\text { Jenis kelamin dewan } \\
\text { direksi }\end{array}$ & $-5,52$ & 0,063 & Tidak signifikan & Tidak terbukti \\
\hline $\begin{array}{l}\text { Ukuran } \\
\text { manajemen risiko }\end{array}$ & $-3,787$ & 0,006 & Signifikan & Terbukti \\
\hline Ukuran perusahaan & $-1,811$ & 0,611 & Tidak signifikan & Tidak terbukti \\
\hline Kerugian & $-0,63$ & 0,074 & Tidak signifikan & Tidak terbukti \\
\hline
\end{tabular}

Sumber: Data sekunder diolah (2021)

Hasil uji t menunjukkan bahwa kualitas audit, ukuran komite audit, pergantian auditor, keahlian dewan direksi, jenis kelamin dewan direksi, ukuran perusahaan, dan kerugian tidak mempengaruhi audit report lag perusahaan finansial periode 2014-2018. Penelitian ini berhasil membuktikan bahwa variabel ukuran dewan direksi dan ukuran komite manajemen risiko berkorelasi negatif serta variabel frekuensi pertemuan dewan direksi memiliki signifikansi positif terhadap audit report lag.

Tabel 5 Hasil Uji Koefisien Determinasi

\begin{tabular}{|l|l|}
\hline Variabel Dependen & Adjusted $\boldsymbol{R}$ Square \\
\hline Audit report lag & 0,7480 \\
\hline
\end{tabular}

Sumber: Data sekunder diolah (2020)

\section{PEMBAHASAN}

\section{$\mathbf{H}^{1}$ : Kualitas audit berpengaruh signifikan terhadap audit repot lag}

Hasil pengujian terhadap variabel kualitas audit menunjukkan bahwa tidak terdapat pengaruh signifikan terhadap audit report lag. Hasil uji kualitas audit ini sesuai dengan penelitian yang dilakukan oleh Hilendri et al. (2017) dan Abdillah et al. (2019). Jenis ukuran kantor akuntan publik Big 4 dan Non-Big 4 menunjukkan tidak terdapat perbedaan yang jauh terkait dengan jangka waktu pelaporan keuangan. Kantor akuntansi publik baik Big 4 dan Non-Big 4 dinilai bekerja secara efesien dan efektif dalam penyelesaian laporan audit untuk mempertahankan kepuasan klien. Baldacchino et al. (2017) menyebutkan bahwa meskipun pekerjaan auditor sangat bergantung pada 
cara klien melakukan bisnis, auditor memiliki tanggung jawab untuk menggunakan kompetensi profesional dan sumber daya yang tersedia untuk kepentingan terbaik klien.

\section{$\mathbf{H}^{2}$ : Ukuran komite audit berpengaruh signifikan terhadap audit report lag}

Ukuran komite audit tidak memiliki hubungan signifikan terhadap audit report lag. Ukuran komite audit sesuai dengan ketentuan minimal adalah tiga orang, dan rata-rata perusahaan finansial yang digunakan dalam penelitian ini menunjukkan sejumlah tujuh orang. Percepatan penyampaian laporan keuangan dinilai bukan tugas utama dari komite audit. Hal ini dikarenakan terdapat risiko inheren yang melekat pada kualitas laporan keuangan. Penelitian ini bertolak belakang dengan penelitian yang dilakukan oleh Firnanti dan Karmudiandri (2020) dimana dijelaskan bahwa ukuran komite audit diekspektasikan dapat meminimalkan audit report lag.

\section{$\mathbf{H}^{3}$ : Pergantian auditor berpengaruh signifikan terhadap audit report lag}

Variabel pergantian auditor pada hasil uji t menunjukkan hubungan tidak signifikan terhadap audit report lag. Penelitian ini mendukung penelitian Megayanti dan Budiartha (2016). Pergantian auditor dinilai tidak mempengaruhi cepat atau lambatnya penyampaian laporan keuangan. Perubahan auditor yang dilakukan oleh perusahaan tidak memberikan pengaruh dalam target waktu penyelesaian audit.

\section{$\mathrm{H}^{4}$ : Ukuran dewan direksi berpengaruh signifikan terhadap audit report lag}

Ukuran dewan direksi memiliki hubungan signifikan positif terhadap audit report lag. Sehingga hipotesis diterima. Hasil penelitian ini mengemukakan bahwa dengan jumlah anggota direksi yang meningkat menyebabkan kesulitan dalam mencapai suatu kesepakatan. Firnanti dan Karmudiandri (2020) menyatakan bahwa direksi bertanggung jawab dalam memantau kualitas informasi yang terkandung dalam laporan keuangan yang dipublikasikan kepada publik.

\section{$\mathrm{H}^{5}$ : Frekuensi pertemuan dewan direksi berpengaruh signifikan terhadap audit report lag}

Hipotesis 5 terbukti dengan ditemukannya hubungan signifikan positif terhadap audit report lag. Ahmed dan Che-Ahmad (2016) menyatakan bahwa frekuensi pertemuan dewan direksi mampu mempersingkat audit report lag. Pertemuan yang rutin dalam membahas permasalahan perusahaan yang membantu proses penyusunan laporan keuangan, Hasil penelitian ini sesuai dengan penelitian yang dilakukan oleh Firnanti dan Karmudiandri (2020).

\section{$\mathrm{H}^{6}$ : Keahlian dewan direksi berpengaruh signifikan terhadap audit report lag}

Hipotesis 6 tidak terbukti dalam penelitian ini. Dimana keahlian dewan direksi tidak berpengaruh signifikan terhadap audit report lag. Kehadiran keahlian dewan direksi dinilai memperpanjang waktu audit report lag. Hasil penelitian ini mendukung penelitian yang telah dilakukan oleh Ahmed dan Che-Ahmad (2016) dan Salleh et al. (2017).

\section{$\mathbf{H}^{\mathbf{7}}$ : Jenis Kelamin dewan direksi berpengaruh signifikan terhadap audit report lag}

Hasil penelitian ini menunjukkan bahwa jenis kelamin dewan direksi tidak berpengaruh terhadap audit report lag pada perusahan finansial yang terdaftar di Bursa Efek Indonesia. Hal ini dikarenakan batas waktu penyampaian laporan keuangan adalah empat bulan sejak tahun buku berakhir dan telah diatur dalam peraturan yang mengikat. Sehingga jenis kelamin dewan direksi (CEO perempuan maupun laki-laki) tidak mempengaruhi ketepatan penyampaian laporan keuangan. Hasil penelitian ini sesuai dengan penelitian yang dilakukan oleh Frischanita (2018), Kayleen dan Harindahyani (2020).

\section{$\mathbf{H}^{8}$ : Ukuran Komite Manajemen Risiko berpengaruh signifikan terhadap audit report lag}

Ukuran komite manajemen risiko menunjukkan pengaruh signifikan negatif terhadap audit report lag. Hal ini membuktikan bahwa dengan hadirnya komite manajemen risiko dalam suatu perusahaan mendukung penurunan jangka waktu audit report lag dan meminimalkan risiko yang akan dihadapi oleh perusahaan atas perspektif negatif investor mengenai keterlambatan penyajian laporan keuangan. Omer et al. (2020) membuktikan bahwa komite manajemen risiko berkorelasi 
dengan audit report lag dan memberikan rekomendasi untuk dilakukan pemisahan tugas secara menyeluruh antara aktivitas manajemen risiko dan komite audit. Hal ini dikarenakan masih ditemukannya komite manajemen risiko dan komite audit yang merangkap.

\section{$\mathbf{H}^{9}$ : Ukuran Perusahaan berpengaruh signifikan terhadap audit report lag}

Pengaruh ukuran perusahaan pada penelitian ini membuktikan bahwa tidak terdapat pengaruh besar kecil ukuran perusahaan terhadap audit report lag. Hasil penelitian ini mendukung hasil penelitian yang telah dilakukan oleh Lianto dan Kusuma (2010), Menajang et al. (2019), dan Hati dan Sari (2020).

\section{$\mathrm{H}^{10}$ : Kerugian berpengaruh signifikan terhadap audit report lag}

Variabel kerugian tidak berkorelasi signifikan dengan variabel dependen pada penelitian ini yaitu audit repot lag. Hossain dan Taylor (1998) menyatakan bahwa laba rugi suatu perusahaan tidak mempengaruhi keterlambatan laporan audit.

\section{KESIMPULAN}

Berdasarkan kajian literatur dan pengujian yang telah dilakukan terdapat variabel independen dan variabel dependen yang digunakan dalam penelitian ini, maka dapat disimpulkan bahwa ratarata audit report lag perusahaan finansial dalam rentang waktu penelitian yakni periode 2014-2018 adalah 70 hari dari tanggal tutup buku tahunan dan telah mematuhi peraturan yang berlaku. Penelitian ini menunjukkan bahwa hanya variabel ukuran dewan, frekuensi pertemuan dewan direksi, dan ukuran komite manajemen risiko yang terbukti signifikan terhadap audit report lag, sedangkan variabel lainnya menunjukkan hasil sebaliknya. Nilai adjusted $R$ square sebesar $74,80 \%$ yang menunjukkan pengaruh antara variabel independen terhadap audit report lag. Sedangkan 25,20\% lainnya dipengaruhi oleh aspek-aspek lain diluar model penelitian ini. Implikasi terapan dari penelitian ini menunjukkan perusahaan finansial cenderung menyampaikan laporan tahunan secara tepat waktu. Perusahaan diharapkan dapat konsisten dalam peningkatan kualitas ketepatan penyampaian laporan tahunan sehingga informasi-informasi penting yang disajikan dapat diperoleh pengguna informasi secara tepat sebagai dasar pertimbangan dalam keputusan investasi. Kekurangan dalam penelitian ini antara lain: (1) terdapat sejumlah perusahaan finansial di BEI yang tidak menerbitkan laporan yang lengkap sehingga hal ini menyebabkan ada beberapa data yang tidak bisa diuji pada penelitian ini. (2) pada laporan keuangan terdapat informasi belum lengkap sehingga terdapat kendala dalam pengumpulan data. Peneliti percaya bahwa masih terdapat peluang yang signifikan mengenai penelitian lebih lanjut pada area topik penelitian ini. Saran yang dapat diberikan untuk digunakan dalam penelitian berikutnya berupa (1) Memperpanjang rentang tahun agar mendapatkan sampel lebih banyak pada penelitian ini. (2) untuk penelitian selanjutnya disarankan menemukan apakah ada pengaruh struktur kepemilikan dan perluasan sektor penelitian.

\section{REFERENSI}

Abdillah, M. R., Mardijuwono, A. W., \& Habiburrochman, H. (2019). The Effect of Company Characteristics and Auditor Characteristics to Audit Report Lag. Asian Journal of Accounting Research, 4(1), 129-144. https://doi.org/10.1108/ajar-05-2019-0042

Ahmed, M. I., \& Che-Ahmad, A. (2016). Effects of Board Size, Board Committees Characteristics and Audit Quality on Audit Report Lags. International Soft Science Conference, 2009, 810 818. https://doi.org/10.15405/epsbs.2016.08.114

Al-Juaidi, O., \& Al-Afifi, A. A. M. (2016). The Factors Affecting Timeliness of Corporate Financial Reporting: Empirical Evidence from the Palestinian and Amman Stock Exchange. International Journal of Management Sciences and Business Research, 5(10), 123-135.

Arif, A., \& Nauman Anees, A. (2012). Liquidity Risk and Performance of Banking System. Journal of Financial Regulation and Compliance, 20(2), 182-195. https://doi.org/10.1108/13581981211218342

Ashton, R. H., Graul, P. R., \& Newton, J. D. (1989). Audit delay and the timeliness of corporate reporting. Contemporary Accounting Research, 5(2), 657-673. https://doi.org/10.1111/j.1911-3846.1989.tb00732.x 
Baldacchino, P. J., Grech, L., Farrugia, K., \& Tabone, N. (2017). An Analysis of Audit Report Lags in Maltese Companies. Contemporary Studies in Economic and Financial Analysis, 98, 161182. https://doi.org/10.1108/S1569-375920160000098010

Kepala Badan Pengawa Pasar Modal. (1997). Keputusan Kepala Badan Pengawa Pasar Modal Nomor KEP-11/PM/1997, Tentang Perubahan Peraturan Nomor IX.C.7 Tentang Pedoman Mengenai Bentuk dan Isi Pernyataan Pendaftaran dalam Rangka Penawaran Umum oleh Perusahaan Menengah atau Kecil. Jakarta, 1997.

Bhuiyan, M. B. U., \& D'Costa, M. (2020). Audit Committee Ownership and Audit Report Lag: Evidence from Australia. International Journal of Accounting and Information Management, 28(1), 96-125. https://doi.org/10.1108/IJAIM-09-2018-0107

Dimitropoulos, P. E., \& Asteriou, D. (2010). The Effect of Board Composition on The Informativeness and Quality of Annual Earnings: Empirical Evidence From Greece. Research in International Business and Finance, 24(2), 190-205. https://doi.org/10.1016/j.ribaf.2009.12.001

Forum for Corporate Governance in Indonesia (2002). Peranan Dewan Komisaris dan Komite Audit dalam Pelaksanaan Corporate Governance (Tata Kelola Perusahaan).

Firnanti, F., \& Karmudiandri, A. (2020). Corporate Governance and Financial Ratios Effect on Audit Report Lag. Accounting and Finance Review, 5(1), 15-21. https://doi.org/10.35609/afr.2020.5.1(2)

Frischanita, Y. (2018). A comparative study of the effect of institutional ownership, audit committee, and gender on audit report lag in Indonesia, Malaysia, and Singapore. The Indonesian Accounting Review, 8(2), 131-143. https://doi.org/10.14414/tiar.v8i2.1658

Fujianti, L., \& Satria, I. (2020). Firm size, profitability, leverage as determinants of audit report lag: Evidence from Indonesia. International Journal of Financial Research, 11(2). https://doi.org/10.5430/ijfr.v11n2p61

Harjoto, M. A., Laksmana, I., \& Lee, R. (2015). The impact of demographic characteristics of CEOs and directors on audit fees and audit delay. Managerial Auditing Journal, 30(8/9), 963997.

Hati, R. P., \& Sari, I. R. (2020). Faktor-Faktor Yang Mempengaruhi Audit Report Lag Pada Perusahaan Perbankan Yang Terdaftar Di Bursa Efek Indonesia (Tahun 2013-2017). Measurement : Jurnal Akuntansi, 14(1), 41-47. https://doi.org/10.33373/mja.v14i1.2509

Herawaty, V., \& Rusmawan, M. F. (2019). Pengaruh Audit Firm Status, Adit Complexity, Kepemilikan Keluarga, Dan Loss Terhadap Audit Report Lag Dengan Spesialisasi Industri Sebagai Variabel Moderasi. Prosiding Seminar Nasional Pakar Ke 2 Tahun 2019, 2.

Hilendri, B. A., Bambang, \& Yuliana, Y. (2017). Pengaruh Good Corporate Governance Terhadap Audit Report Lag dengan Ketepatan Waktu Penyampaian Laporan Keuangan sebagai Variabel Moderasi. Jurnal Aplikasi Akuntansi, 2(1).

Hossain, M. A., \& Taylor, P. J. (1998). An examination of audit delay: Evidence from Pakistan. http://www3.bus.osaka-cu.ac.jpapira98archivespdfs64.pdf

Ika, S. R., \& Mohd Ghazali, N. A. (2012). Audit committee effectiveness and timeliness of reporting: Indonesian evidence. Managerial Auditing Journal, 27(4), 403-424. https://doi.org/10.1108/02686901211217996

Indriantoro, N., \& Supomo, B. (2016). Metodologi Penelitian Bisnis. BPFE.

Jaggi, B., \& Tsui, J. (1999). Determinants of audit report lag: Further evidence from Hong Kong. Accounting and Business Research, 30(1), 17-28. https://doi.org/10.1080/00014788.1999.9728921

Jao, R., \& Crismayani, F. P. (2018). Pengaruh Mekanisme Corporate Governance Terhadap Audit Delay. Prosiding Seminar Hasil Penelitian (SNP2M) Politeknik Negeri Ujung Pandang, 2018(2015), 87-92. www.idx.co.id.

Jensen, M. C., \& Meckling, W. H. (1976). Theory of The Firm: Managerial Behavior, Agency Cost and Ownership Structure. Journal of Financial Economics 3, 305-360.

Jiraporn, P., Miller, G. A., Yoon, S. S., \& Kim, Y. S. (2008). Is earnings management opportunistic or beneficial? An agency theory perspective. International Review of Financial Analysis, 17(3), 622-634. https://doi.org/10.1016/j.irfa.2006.10.005 
Joened, J. A., \& Damayanthi, I. G. A. E. (2016). Pengaruh Karakteristik Dewan Komisaris, Opini Auditor, Profitabilitas, Dan Reputasi Auditor Pada Timeliness of Financial Reporting. EJurnal Akuntansi Universitas Udayana, 14(1), 423-450.

Juanita, G., \& Satwiko, R. (2012). Pengaruh Ukuran Kantor Akuntan Publik, Kepemilikan, Laba Rugi, Profitabilitas dan Solvabilitas terhadap Audit Report Lag. Jurnal Bisnis Dan Akuntansi, 14(1), 31-40.

Kayleen, K., \& Harindahyani, S. (2020). The Impact of Audit Committee's Effectiveness, Gender, and Tenure on Audit Report Lag: Indonesian Evidence. Conference: Proceedings of the 1st International Conference on Business, Law And Pedagogy, ICBLP 2019. https://doi.org/10.4108/eai.13-2-2019.2286077

Klein, A. (1998). Firm Performance and Board Committee Structure. The Journal of Law and Economics, 41(1), 275-304. https://doi.org/10.1086/467391

Kuslihaniati, D. F., \& Hermanto, S. B. (2016). Pengaruh Praktik Corporate Governance dan Karakteristik Perusahaan terhadap Audit Report Lag. Jurnal Ilmu Dan Riset Akuntansi, 5(2), $1-22$.

Lianto, N., \& Kusuma, H. (2010). Faktor-Faktor Yang Berpengaruh Terhadap Audit Report Lag. Diponegoro Journal of Accounting, 12(2), 98-107.

Megayanti, P., \& Budiartha, I. (2016). Pengaruh Pergantian Auditor, Ukuran Perusahaan, Laba Rugi Dan Jenis Perusahaan Pada Audit Report Lag. E-Jurnal Akuntansi Universitas Udayana, 14(2), 1481-1509.

Menajang, M. J. O., Elim, I., \& Runtu, T. (2019). Analisis Pengaruh Ukuran Perusahaan, Profitabilitas, Dan Solvabilitas Terhadap Audit Report Lag (Studi Kasus Perusahaan Property dan Real Estate Yang Terdaftar Di Bursa Efek Indonesia). Jurnal EMBA: Jurnal Riset Ekonomi, Manajemen, Bisnis dan Akuntansi, 7(3), 3478-3487. https://doi.org/10.35794/emba.v7i3.24563

Otoritas Jasa Keuangan. (2014). Peraturan Otoritas Jasa Keuangan Nomor 33/POJK.04/2014, Tentang Direksi dan Dewan Komisaris Emiten atau Perusahaan Publik. Jakarta: Otoritas Jasa Keuangan, 2014.

Otoritas Jasa Keuangan. (2015). Peraturan Otoritas Jasa Keuangan Nomor 1/POJK.05/2015, Tentang Penerapan Manajemen Risiko Bagi Lembaga Jasa Keuangan Non-Bank. Jakarta: Otoritas Jasa Keuangan, 2015.

Otoritas Jasa Keuangan. (2015). Peraturan Otoritas Jasa Keuangan Nomor 55/POJK.04/2015, Tentang Pembentukan dan Pedoman Pelaksanaan Kerja Komite Audit. Jakarta: Otoritas Jasa Keuangan, 2015.

Otoritas Jasa Keuangan. (2016). Peraturan Otoritas Jasa Keuangan Nomor 18/POJK.03/2016, Tentang Penerapan Manajemen Risiko Bagi Bank Umum. Jakarta: Otoritas Jasa Keuangan, 2016.

Otoritas Jasa Keuangan. (2016). Peraturan Otoritas Jasa Keuangan Nomor 29/POJK.04/2016, Tentang Laporan Keuangan Emiten atau Perusahaan Publik. Jakarta: Otoritas Jasa Keuangan, 2016.

Omer, W. K. H., Aljaaidi, K. S., \& Al-Moataz, E. S. (2020). Risk Management Functions And Audit Report Lag Among Listed Saudi Manufacturing Companies. Journal of Asian Finance, Economics and Business, 7(8), 61-67. https://doi.org/10.13106/JAFEB.2020.VOL7.NO8.061

Putri, A. N. I., \& Januarti, I. (2014). Faktor Faktor Yang Berpengaruh Terhadap Audit Report Lag Pada Perusahaan Manufaktur yang Terdaftar di Bursa Efek Indonesia Periode Tahun 20082012. Diponegoro Journal of Accounting, 3(2).

Pradipta, A., \& Zalukhu, A. G. (2014). Audit Report Lag: Specialized Auditor and Corporate Governance. Global Journal of Business and Social Science Review, 8(1), 41-48. https://doi.org/10.35609/gjbssr.2020.8.1(5).

Rezaei, F. M., \& Saleh, N. M. (2016). Audit Report Lag: The Role of Auditor Type and Increased Competition in The Audit Market. Accounting and Finance.

Salleh, Z., Baatwah, S. R., \& Ahmad, N. (2017). Audit Committee Financial Expertise and Audit Report Lag: Malaysia Further Insight. Asian Journal of Accounting and Governance, 8, $137-$ 150. https://doi.org/10.17576/ajag-2017-08-12 
Sujarweni, V. W. (2016). Pengantar Akuntansi. Pustaka Baru Press.

Suryono, H., \& Prastiwi, A. (2011). Pengaruh Karakteristik Perusahaan Dan Corporate Governance (CG) Terhadap Praktik Pengungkapan Sustainability Report (SR) ( Studi Pada Perusahaan Perusahaan yang Listed (Go-Public) di Bursa Efek Indonesia (BEI) Periode 2007 - 2009 ). Simposium Nasional Akuntansi XIV Aceh 2011, 21-22.

Sylviana, D. (2019). Pengaruh Solvabilitas, Pergantian Auditor dan Opini Auditor Terhadap Audit Delay. Seminar Nasional Teknologi Komputer \& Sains (SAINTEKS), 92-95.

Ustman, U. (2020). The Effect of Solvency, Firm Size, Age Companies on Audit Report Lag in Indonesian Company. Research Journal of Finance and Accounting, 11(2), 17-22. https://doi.org/10.7176/rjfa/11-2-02

Violita, R., \& Sulasmiyati, S. (2017). Pengaruh Struktur Modal Terhadap Profitabilitas (Studi Pada Perusahaan Food and Baverages Yang Terdaftar di BEI Tahun 2013-2016). Jurnal Administrasi Bisnis, 51(1), 138-144.

Weygandt, Kimmel, \& Kieso. (2013). Financial Accounting: IFRS Edition. John Wiley \& Sons, Inc. 